\title{
PENGARUH PENGGUNAAN SOFTWARE CABRI 3D TERHADAP MINAT DAN HASIL BELAJAR MATEMATIKA PADA POKOK BAHASAN BANGUN RUANG
}

\author{
Ilham Maulana ${ }^{1}$, Saluky $^{2}$, dan Muhammad Ali Misri ${ }^{3}$ \\ Tadris Matematika \\ Institut Agama Islam Negeri (IAIN) Syekh Nurjati Cirebon \\ E-mail: ilham.elbaladie94@gmail.com ${ }^{1)}, \underline{\text { luke4line@gmail.com }}{ }^{2}$, $\underline{\text { alimisri@gmail.com }}$ (3)
}

\begin{abstract}
Advances in technology and information can not be separated from the scope of human life including in education. The quality of education will increase as technology completes education because education will grow in harmony with the development of the world. Therefore, it is necessary to hold learning using technology-based learning media, especially computers. Efforts to use instructional media in the classroom is to use the 3D Cabri Software. This study aims to: 1) To determine the student response to the use of $3 D$ Cabri Software on the subject of wake up space. 2) To know interest and learning result of learning on the subject matter of waking up. 3) To find out how much influence the use of 3D Cabri Software to interest and learning outcomes on the subject of wake up space. Cabri 3D Software is a software geometry that is used for visualization and development of reason to build three-dimensional space, it is expected to be the main capital for learners in improving the intelligence of reasoning and visual spatial. The method used in this research is quantitative method with before-after type with purposive sampling sampling technique. The results showed that: 1) Student response to the use of 3D Cabri software has an average of $67 \%$ with good category 2) There is influence of the use of 3D Cabri Software to interest and learning result seen from t test, that is $t$ calculate for learning interest equal to 10,600 And t arithmetic for learning result equal to 10,146 and t table equal to 2,048, then $t$ count $>$ from $t$ table. The interpretation is that there is a significant influence on students' interest and learning outcomes. Student learning outcomes increased as seen from the mean score before using the 3D Cabri software obtained 77.38 and the mean score after using the 3D Cabri software was obtained 82.86. While interest in student learning increased seen from the change of questionnaire of student interest before and after that is equal to 4\%. Based on this, the 3D Cabri Software is very feasible and helps to serve as a medium in learning mathematics.
\end{abstract}

Keywords: 3D Cabri Software, IT, Learning Outcomes, Mathematics, Build Space.

\section{PENDAHULUAN}

Di zaman yang semakin modern ini, pesatnya kemajuan Teknologi Informasi dan Komunikasi (TIK) telah menyebar hampir ke setiap aspek. Teknologi dapat membuat hidup lebih mudah dan lebih baik. Seperti dalam halnya pekerjaan yang dilakukan manusia secara manual kini dapat digunakan dengan mesin. Hal ini menuntut manusia untuk berfikir lebih maju dalam segala hal agar tidak dianggap tertinggal. Komputer sebagai salah satu bentuk dari kemajuan dibidang ilmu pengetahuan dan teknologi dapat dimanfaatkan oleh manusia sebagai teknologi informasi dan komunikasi sehingga dapat mendorong manusia untuk lebih meningkatkan efisiensi dan efektifitasnya. Oleh karena itu, dengan komputer akan memudahkan siswa dalam belajar.

Saat ini hampir setiap sekolah telah mempunyai laboratorium komputer. Komputer-komputer di laboratorium sekolah tersebut pada umumnya hanya digunakan untuk kepentingan administrasi, seperti mengetik surat, mengetik laporan, membuat daftar gaji, dan sebagainya. Masih jarang sekolah yang menggunakan komputer untuk pembelajaran. Kalaupun ada, sebagian besar komputer hanya digunakan untuk mata pelajaran komputer itu sendiri (TIK). Mungkin hal ini disebabkan guru bidang studi (termasuk bidang studi Matematika), belum mampu menggunakan programprogram komputer tersebut dalam pembelajaran. Belajar merupakan proses seseorang untuk dapat mengetahui, memahami dan dapat melakukan dari hal yang tadinya belum diketahui, dipahami dan tidak dapat dilakukan. Belajar bertujuan untuk mengarahkan perubahan pada diri siswa secara terencana, baik dalam aspek pengetahuan keterampilan maupun sikap. Proses belajar yang kurang maksimal dapat menyebabkan hasil belajar yang kurang maksimal. Hasil belajar adalah kemampuankemampuan yang dimiliki siswa setelah ia menerima pengalaman belajarnya. Pengalaman belajar siswa diperoleh dari 
proses belajar siswa, maka proses belajar siswa dapat mempengaruhi hasil belajar siswa (Sudjana, 2002).

Guru dalam kegiatan pembelajaran memerlukan alat atau media sebagai perantara penyampaian materi, salah satunya adalah komputer. Bambang Warsita (2008 : 137) menyatakan bahwa media pemelajaran berbasis komputer, atau biasa disebut pembelajaran berbantuan komputer (Computer Assisted Instructional/CAI) adalah salah satu media pembelajaran yang sangat menarik dan mampu meningkatkan motivasi belajar peserta didik. Komputer dapat digunakan sebagai alat untuk menyampaikan informasi atau ide-ide yang terkandung dalam pembelajaran kepada peserta didik. Selain itu, komputer juga dapat digunakan sebagai media yang memungkinkan peserta didik belajar secara mandiri (Darmawan 2012).

Cabri 3D merupakan software yang akan diterapkan dan diuji cobakan dalam penelitian ini. Software ini digunakan sebagai media pembelajaran berbasis informasi dan teknologi. Cabri $3 D$ merupakan program komputer khusus matematika yang dapat digunakan sebagai media pembelajaran untuk materi Bangun Ruang. Bangun ruang merupakan materi yang akan dibahas dalam penelitian ini. Bentuk dari materi tersebut memiliki beberapa karakteristik atau sifat-sifat yang terbentuk dari beberapa bangun ruang. Siswa dapat langsung mengetahui karakteristik materi tersebut dan di praktekkan dengan menggunakan software Cabri 3D.

Geometri adalah materi pelajaran matematika yang membutuhkan kemampuan matematis yang cukup baik untuk memahaminya.Siswa sering mengalami kesulitan dalam memahami materi Geometri, siswa cenderung menghafal materi dari pada memahaminya. Belajar dengan menghafal kurang efektif karena siswa akan mudah lupa dan cara berpikir siswa menjadi tidak kreatif. Siswa dapat memahami materi jika siswa tersebut dapat mengeksplorasi atau menemukan sendiri pemecahan masalahnya. Untuk membantu siswa belajar memahami materi bangun ruang, siswa dapat menggunakan aplikasi komputer software Cabri $3 D$.
Berdasarkan uraian di atas peneliti ingin mengetahui bagaimana pengaruh Software Cabri $3 D$ terhadap minat dan hasil belajar siswa pada pokok bahasan Bangun ruang. Oleh sebab itu, peneliti terdorong untuk melakukan penelitian "Pengaruh Software Cabri $3 D$ terhadap minat dan hasil belajar siswa pada pokok bahasan Bangun ruang".

\section{LANDASAN TEORI}

\section{Media Pembelajaran}

Kata media berasal dari bahasa latin medius yang secara harfiah berarti tengah, perantara atau pengantar. Dalam bahasa Arab media adalah perantara atau pengantar pesan dari pengirim kepada penerima pesan (Azhar Arsyad, 2011:3). Menurut Gerlach dan Ely yang dikutip oleh Azhar Arsyad (2011), media apabila dipahami secara garisbesar adalah manusia, materi dan kejadian yang membangun kondisiyang membuat siswa mampu memperoleh pengetahuan, ketrampilan atau sikap. Dalam pengertian ini, guru, buku teks, dan lingkungan sekolah merupakan media. Secara lebih khusus, pengertian media dalam proses belajar mengajar cenderung diartikan sebagai alat-alat grafis, photografis, atau elektronis untk menangkap, memproses, dan menyusun kembali informasi visual dan verbal.

Berdasarkan beberapa pendapat di atas dapat disimpulkan bahwa media adalah segala sesuatu benda atau komponen yang dapat digunakan untuk menyalurkan pesan dari pengirim ke penerima sehingga dapat merangsang pikiran, perasaan, perhatian dan minat siswa dalam proses belajar. Media pembelajaran adalah sarana penyampaian pesan pembelajaran kaitannya dengan model pembelajaran langsung yaitu dengan cara guru berperan sebagai penyampai informasi dan dalam hal ini guru seyogyanya menggunakan berbagai media yang sesuai. Media pembelajaran adalah alat bantu proses belajar mengajar. Segala sesuatu yang dapat dipergunakan untuk merangsang pikiran, perasaan, perhatian dan kemampuan atau keterampilan pebelajar sehingga dapat mendorong terjadinya proses belajar.

Menurut Briggs (1977) dalam Ahmad Fauzi (2014:256) media pembelajaran adalah 
sarana fisik untuk menyampaikan isi/materi pembelajaran seperti : buku, film, video dan sebagainya. Sedangkan menurut Heinich yang dikutip oleh Azhar Arsyad (2011:4), media pembelajaran adalah perantara yang membawa pesan atau informasi bertujuan instruksional atau mengandung maksudmaksud pengajaran antara sumber dan penerima.

\section{Media Berbasis IT}

Teknologi informasi (Information Technology) yang mulai populer di akhir tahun 70-an, dihantarkan untuk menjawab tantangan. Pada masa sebelumnya, istillah teknologi komputer atau pengolahan data elektronis atau EDP (Electronic Data Processing). Menurut kamus Oxford (1995), teknologi informasi adalah studyi atau penggunaan peralatan elektronika, terutama komputer untuk menyimpan, menganalisis, dan mendistribusikan informasi apa saja, termasuk kata, bilangan dan gambar. Menurut Alter (1992), teknologi informasi mencakup perangkat keras dan perangkat lunak untuk melaksanakan satu atau sejumlah tugas pemrosesan data seperti menangkap mentransmisikan, menyimpan, mengambil, memanipulasi, atau menampilkan data. (Darmawan 2012).

\section{Pengertian Software}

Perangkat Lunak (software) adalah kumpulan beberapa perintah yang dieksekusi oleh mesin komputer dalam menjalankan pekerjaannya. perangkat lunak ini merupakan catatan bagi mesin komputer untuk menyimpan perintah, maupun dokumen serta arsip lainnya. Perangkat Lunak (software) merupakan data elektronik yang disimpan sedemikian rupa oleh komputer itu sendiri, data yang disimpan ini dapat berupa program atau instruksi yang akan dijalankan oleh perintah, maupun catatan-catatan yang diperlukan oleh komputer untuk menjalankan perintah yang dijalankannya. Untuk mencapai keinginannya tersebut dirancanglah suatu susunan logika, logika yang disusun ini diolah melalui perangkat lunak, yang disebut juga dengan program beserta data-data yang diolahnya. Pengeloahan pada software ini melibatkan beberapa hal, diantaranya adalah sistem operasi, program, dan data. Software ini mengatur sedemikian rupa sehingga logika yang ada dapat dimengerti oleh mesin komputer.

Menurut Susanto dalam Deni Darmawan (2012) Software adalah kumpulan program yang digunakan untuk menjalankan aplikasi tertentu pada komputer, sedangkan program komputer merupakan kumpulan perintah komputer yang tersusun secara sistematis. Sementara menurut Daryanto (2010) software (perangkat lunak) adalah kumpulan data serta instruksi yang memberi sifat "hidup" pada komputer.

\section{Software Cabri $3 D$}

$$
\text { Cabri 3D merupakan }
$$
software geometri interaktif. Software ini merupakan pengembangan dari software geometri Cabri II. Software ini di produksi di Perancis oleh Jean Marie Laborde dan Max Marcadet pada tahun 2004. Cabri 3D mampu menyajikan objek geometri yang sangat baik dan dapat dilihat dari berbagai sudut pandang serta mampu menentukan hubungan antara objek-objek tersebut. Menurut Anthony (2006) hasil penelitian menunjukan bahwa Cabri $3 D$ memiliki dasar yang sangat kuat dalam membantu proses pembelajaran matematika khususnya geometri, karena mampu membantu memvisualisasikan konsep geometri.

Cabri 3D tidak hanya digunakan sebagai software yang mempresentasikan matematika secara geometri tetapi juga dapat digunakan secara umum untuk membangun kemudahan bermatematika dengan memunculkan bentuk-bentuk yang menyerupai keaslian dari berbagai model. Software ini memberikan kemudahan bagi siswa dan guru untuk mengeksplorasi berbagai bentuk dan model geometri. Siswa bisa lebih aktif dalam pembelajaran dengan melakukan eksplorasi di bawah bimbingan guru. Software ini juga memberikan kemudahan kepada siswa untuk lebih mampu membuktikan teori dan konsep secara mandiri dengan menggunakan sedikit perhitungan dan manipulasi sederhana.

\section{Perkembangan Cabri}

Tahun 1985, Jean-Marie Laborde seorang saintis computer matematikawan, dan peneliti pada matematika diskrit, mengemukakan sebuah penemuan berupa buku tentang garis-garis besar dari 
geometri. "Cabri-geometre" menjabarkan sebuah eksplorasi dari sifat-sifat objek-objek matematika dan hubungan antara setiap sifat dan objek tersebut.

Dimulai dari tahun 1990 sebuah proyek besar di Computer Science and Applied Mathematics Institute in Grenoble (IMAG) dimulai dengan mengumpulkan para peneliti komputer sains, ahli matematika, ahli-ahli kecerdasan buatan dan psikologi dan juga guru-guru. Proyek ini bertempat di laboratorium LSD2, dan juga sekolahsekolah di Grenoble. Selama tahun 90-an generasi pertama dari Cabri-geometre telah dihasilkan yang merupakan generasi baru cikal bakal "Cabri II" yang dikembangkan oleh Jean-Marie Laborde, Franck Bellemain dan Sylvie Tessier sebagai pendukung peralatan industri di Texas. Kerja sama antara Cabri-geometre dan Texas Instruments mempercepat pengkondisian pembelajaran matematika dengan adanya kalkulator yang mempunyai vasilitas perhitungan dan dinamik geometri dengan nama TI-92.

Awal tahun 2000 Jean-Marie Laborde mendirikan The Company Cabrilog untuk mengembangkan software Cabri dan memproduksi versi barunya untuk komputer dan kalkulator. Di awal 2003 versi baru dihasilkan, Cabri Geometry II Plus, diikuti software geometri baru : Cabri Junior untuk kalkulator TI83 dan TI84. September 2007 dikembangkan Cabri Geometry II Plus dilanjutkan dengan versi 1.4. Pada Sepember 2004 di Cabriworld di Roma, Jean-Marie Laborde menembangkan Cabri Geometry II plus for MacOS X. Pada saat yang sama muncul pula produk baru Cabri $3 D$, sebuah software geometri interaktif. Sekarang versi terbarunya Cabri $3 D$ dilengkapi peralatan numeric dan geometri dan peralatan visualisasi 3D yang unik. Cabri $3 D$ memenangkan BETT awards 2007 diperlombaan digital yang bergengsi.

Program Cabri 3D V2 berguna untuk memfasilitasi siswa dalam mengkonstruksi obyek-obyek geometri, akan tetapi kurang efektif apabila guru tidak mengontrol kegiatan belajar, namun hal ini dapat di atasi dengan meminta siswa mengkonstruksi obyek-obyek geometri sesuai dengan langkah-langkah konstruksi yang telah disiapkan. Secara umum program Cabri 3D V2 terdiri dari Menu, Toolbar, dan Drawing
Area. Pada bagian menu ditampilkan File, Edit, Display, Document, Window, dan Help. Pada bagian Toolbar ditampilkan toolbox yang daat digunakan untuk menciptakan dan memodifikas satu figur. Toolbox terdiri dari Manipulation, Points, Curves, Relative Construction, Regular Polygons, Polyhedra, Regular Polyhedra (Platonic Solids), Measurement and, Calculation Tools dan transformations.

\section{Kelebihan Cabri 3D}

> Gambar-gambar bangun geometri yang biasanya dilakukan menggunakan bangun baik berupa kerangka bangun maupun ruang dari jaring-jaring dapat dibuat dengan mudah yang lebih cepat dan teliti.

$>$ Adanya animasi gerakan (dragging) dapat memberikan visualisasi dengan jelas.

> Dapat digunakan sebagai alat evaluasi apakah pekerjaan yang dilakukan adalah benar atau salah.

> Memudahkan guru dan siswa untuk menyelidiki sifat-sifat yang berlaku pada suatu objek.

$>$ Mempunyai perintah pengerjaan matematika yang luas.

> Mempunyai suatu antarmuka berbasis worksheet.

> Mempunyai fasilitas pengerjaan yang baik dalam dimensi dua dan dimensi tiga.

> Bahasa pemogramannya memudahkan pemahaman konsep peserta didik.

> Hasil pengerjaannya lebih baik dibandingkan software Autograph dan Maple.

> Mempunyai fasilitas untuk membuat dokumen dalam beberapa format.

\section{Minat Belajar}

Menurut Drs. Dyimyati Mahmud (1982), Minat dalah sebagai sebab yaitu kekuatan pendorong yang memaksa seseorang menaruh perhatian pada orang situasi atau aktifitas tertentu dan bukan pada yang lain, atau minat sebagai akibat yaitu pengalaman efektif yang distimular oleh hadirnya seseorang atau sesuatu obyek, atau karena berpartisipasi dalam suatu aktifitas. 
Berdasarkan definisi minat tersebut dapatlah penulis kemukakan bahwa minat mengandung unsur-unsur sebagai berikut:

1. Minat adalah suatu gejala psikologis

2. Adanya pemusatan perhatian, perasaan dan pikiran dari subyek karena tertarik.

3. Adanya perasaan senang terhadap obyek yang menjadi sasaran

4. Adanya kemauan atau kecenderu ngan pada diri subyek untuk melakukan kegiatan guna mencapai tujuan.

\section{Hasil Belajar}

Hasil belajar merupakan bagian terpenting dalam pembelajaran. Nana Sudjana (2009: 3) mendefinisikan hasil belajar siswa padahakikatnya adalah perubahan tingkah laku sebagai hasil belajar dalam pengertian yang lebih luas mencakup bidang kognitif, afektif, danpsikomotorik. Dimyati dan Mudjiono (2006: 3-4) juga menyebutkan hasil belajar merupakan hasil dari suatu interaksi tindak belajar dantindak mengajar. Dari sisi guru, tindak mengajar diakhiri dengan prosesevaluasi hasil belajar. Dari sisi siswa, hasil belajar merupakanberakhirnya pengajaran dari puncak proses belajar.Benjamin S. Bloom (Dimyati dan Mudjiono, 2006: 26-27) menyebutkan enam jenis perilaku ranah kognitif, sebagai berikut:

a) Pengetahuan, mencapai kemampuan ingatan tentang hal yang telah dipelajari dan tersimpan dalam ingatan. Pengetahuan itu berkenaandengan fakta, peristiwa, pengertian kaidah, teori, prinsip, ataumetode.

b) Pemahaman, mencakup kemampuan menangkap arti dan makna tentang hal yang dipelajari.

c) Penerapan, mencakup kemampuan menerapkan metode dan kaidah untuk menghadapi masalah yang nyata dan baru. Misalnya, menggunakan prinsip.

d) Analisis, mencakup kemampuan merinci suatu kesatuan ke dalam bagian-bagian sehingga struktur keseluruhan dapat dipahami dengan baik. Misalnya mengurangi masalah menjadi bagian yangtelah kecil.

e) Sintesis, mencakup kemampuan membentuk suatu pola baru. Misalnya kemampuan menyusun suatu program.

f) Evaluasi, mencakup kemampuan membentuk pendapat tentang beberapa hal berdasarkan kriteria tertentu. misalnya, kemampuan menilai hasil ulangan.

\section{METODOLOGI PENELITIAN}

Penelitian ini menggunakan metode eksperimen karena pada penelitian ini menggunakan media pembelajaran Software Cabri $3 D$ dan melihat pengaruhnya terhadap hasil belajar matematika peserta didik. Penelitian ini merupakan penelitian yang bersifat kuantitatif, karena data yang akan diolah berhubungan dengan nilai-nilai dan angka-angka yang dapat dihitung secara matematis dengan menggunakan perhitungan statistik.

Adapun langkah-langkah yang akan dilakukan pada setiap tahapan sebagai berikut:

a. Tahap persiapan, meliputi:

1) Menyusun proposal penelitian kemudian dikonsultasikan dengan pembimbing I dan II

2) Melakukan seminar proposal penelitian sehingga mendapat tanggapan saran dan perbaikan proposal yang diajukan.

3) Konsultasi dengan pembimbing untuk memperbaiki proposal penelitian.

4) Mendapat surat keputusan Jurusan Matematika IAIN Syekh Nurjati Cirebon mengenai bimbingan penulisan skripsi sesuai dengan ketentuan berlaku.

5) Membuat surat pengantar penelitian dari Fakultas Ilmu Tarbiyah dan Keguruan untuk diajukan kepada Kepala Sekolah SMP As-syahida Dukupuntang Kab. Cirebon.

6) Pembuatan Instrumen Penelitian.

b. Tahap pelaksanaan

1) Memilih kelas untuk uji coba instrumen penelitian.

2) Menyebar kuesioner kepada peserta didik mengenai minat belajar dengan tujuan uji coba instrumen.

3) Menganalisis data hasil uji coba untuk mengetahui validitas dan reliabilitas angket minat belajar.

4) Menyebar angket yang sudah valid dan reliabel kepada peserta didik kelas eksperimen mengenai minat belajar. 
5) Melaksanakan pembelajaran menggunakan Software Cabri 3D pada materi bangun ruang.

6) Menyebar angket yang sudah valid dan reliabel kepada peserta didik kelas eksperimen mengenai minat belajar.

7) Menyebar angket kepada peserta didik mengenai penggunaan Software Cabri $3 D$ pada materi bangun ruang.

c. Tahap pengolahan data

1) Pengolahan data hasil angket.

2) Analisis data.

3) Membuat kesimpulan dari data yang telah diperoleh.

d. Tahap penulisan laporan hasil penilitian, yakni menyusun laporan secara lengkap.

Desain penelitian yang digunakan pada penelitian ini adalah desain eksperimen before after, sebagai berikut:

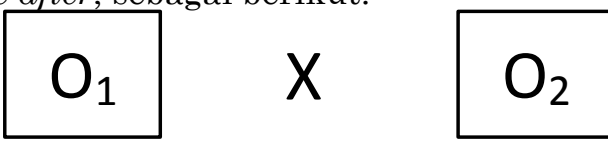

Gambar 3.1 Desain Eksperimen before-after.

$\mathrm{O}_{1}$ nilai sebelum treatment dan $\mathrm{O}_{2}$ nilai sesudah treatment

(Sugiyono, 2011: 415)

Penelitian ini dilaksanakan di SMP Asy-Syahida Dukupuntang yang beralamat di Jl. Nyi Ageng Serang Desa Cangkoak Kecamatan Dukupuntang Kabupaten Cirebon. Populasi dalam penelitian ini yaitu mengambil populasi dari siswa kelas IX A SMP Asy-Syahida Dukupuntang pada tahun pelajaran 2016/2017 dengan jumlah peserta didik 29 siswa.

Pada prinsipnya meneliti merupakan sebuah kegiatan melakukan pengukuran, oleh karena itu alat ukur yang baik pada penelitian sangat diperlukan. Menurut Sugiyono (2011) alat ukur dalam penelitian dinamakan instrument penelitian. Dalam penelitian ini instrument penelitian yang digunakan adalah: (1) lembar validasi materi dan media yang diisi oleh dosen IAIN Syekh Nurjati Cirebon dan guru SMP Asy-Syahida Dukupuntang, (2) lembar angket respon siswa yang divalidasi oleh dosen IAIN Syekh Nurjati Cirebon dan guru SMP Asy-Syahida Dukupuntang dan diisi oleh siswa kelas IX A SMP Asy-Syahida Dukupuntang, (3) soal tes untuk siswa. Untuk lebih jelasnya perhatikan Tabel 1. 
Tabel 1

Instrumen Penelitian

\begin{tabular}{|c|c|c|}
\hline Instrumen & Fungsi & Keterangan \\
\hline $\begin{array}{l}\text { Lembar } \\
\text { Validasi }\end{array}$ & $\begin{array}{l}\text { Untuk } \\
\text { mendapatk } \\
\text { an data } \\
\text { validasi } \\
\text { oleh } \\
\text { validator } \\
\text { sebagai } \\
\text { penguji } \\
\text { kualitas } \\
\text { media } \\
\text { pembelajar } \\
\text { an, agar } \\
\text { dapat } \\
\text { diketahui } \\
\text { kelayakan } \\
\text { media yang } \\
\text { dibuat } \\
\text { sebelum } \\
\text { diujicobaka } \\
\text { n }\end{array}$ & $\begin{array}{l}\text { Validator } \\
\text { media adalah } \\
\text { dua dosen } \\
\text { dan satu guru } \\
\text { dipilih } \\
\text { berdasarkan } \\
\text { keahlian } \\
\text { dibidang } \\
\text { estetika } \\
\text { media } \\
\text { pembelajaran } \\
\text { dan } \\
\text { penguasaan } \\
\text { materi. }\end{array}$ \\
\hline $\begin{array}{l}\text { Angket } \\
\text { Respon } \\
\text { Siswa }\end{array}$ & $\begin{array}{l}\text { Mengetahui } \\
\text { bagaimana } \\
\text { tanggapan } \\
\text { siswa } \\
\text { terhadap } \\
\text { media } \\
\text { pembelajar } \\
\text { an yang } \\
\text { dihasilkan }\end{array}$ & $\begin{array}{l}\text { Angket } \\
\text { respon siswa } \\
\text { diberikan } \\
\text { setelah } \\
\text { kegiatan } \\
\text { pembelajaran } \\
\text { inti mengunaka } \\
\text { m media } \\
\text { pembelajaran } \\
\text { yang dibuat. }\end{array}$ \\
\hline $\begin{array}{l}\text { Angket } \\
\text { Minat } \\
\text { belajar } \\
\text { Siswa }\end{array}$ & $\begin{array}{l}\text { Mengetahui } \\
\text { seberapa } \\
\text { besar minat } \\
\text { siswa } \\
\text { terhadap } \\
\text { pembelajar } \\
\text { an } \\
\text { matematika }\end{array}$ & $\begin{array}{l}\text { Angket minat } \\
\text { belajar siswa } \\
\text { diberikan } \\
\text { sebelum dan } \\
\text { setelah } \\
\text { kegiatan } \\
\text { pembelajaran } \\
\text { inti mengunaka } \\
\text { m media } \\
\text { pembelajaran } \\
\text { yang dibuat. }\end{array}$ \\
\hline Soal Tes & $\begin{array}{l}\text { Untuk } \\
\text { mendapatk } \\
\text { an data } \\
\text { tentang } \\
\text { hasil } \\
\text { belajar atau } \\
\text { ketuntasan } \\
\text { siswa }\end{array}$ & $\begin{array}{l}\text { Soal tes yang } \\
\text { diberikan } \\
\text { kepada siswa } \\
\text { sesuai } \\
\text { dengan } \\
\text { pembahasan } \\
\text { pada media } \\
\text { pembelajaran } \\
\text { yang telah } \\
\text { dibuat dan } \\
\text { diajarkan. }\end{array}$ \\
\hline
\end{tabular}

Penilaian lembar validasi menggunakan rentang kriteria skor angket disesuaikan dengan banyak item butir perntanyaannya sebagai berikut:

Tabel 2

Kriteria Penilaian Ahli

\begin{tabular}{ll}
\hline Penilaian & Kriteria \\
\hline $1-20$ & Sangat Kurang \\
$21-40$ & Kurang \\
$41-60$ & Cukup \\
$61-80$ & Baik \\
$81-100$ & Sangat Baik \\
\hline
\end{tabular}

Penilaian angket respon peserta didik divalidasi oleh pakar ahli (expert judgement) menggunakan rumus CVR sebagai berikut:

$$
C V R=\frac{2 n e}{N}-1
$$

(Toto dan Budi, 2014: 78)

Untuk lebih meyakinkan bahwa peningkatan hasil belajar peserta didik adalah dipengaruhi oleh penggunaan Software Cabri $3 D$, maka dilakukan analisis statistik menggunakan uji prasyarat dan uji hipotesis. Uji prasyarat meliputi uji normalitas dan homogenitas. Sedangkah uji hipotesis meliputi uji korelasi, uji koefisien determinasi, uji independen dan kelinieran regresi, dan uji hipotesis statistik. Peneliti dalam menganalisis adanya pengaruh atau tidak adalah menggunakan software SPSS 20.0 .

\section{HASIL DAN PEMBAHASAN}

Pembelajaran yang efektif adalah pembelajaran memanfaatkan alat bantu (media Pembelajaran yang efektif adalah pembelajaran memanfaatkan alat bantu (media pembelajaran). Dengan adanya media pembelajaran, siswa akan lebih mudah memahami pelajaran matematika. Oleh sebab itu, pembelajaran dengan memanfaatkan media pembelajaran Software Cabri $3 D$ sebagai salah satu media yang mengajak siswa untuk lebih aktif dan mudah dalam proses pembelajaran di kelas.

Penelitian ini menggunakan Software Cabri $3 D$ pada kelas IX A SMP Asy-Syahida Dukupuntang Kab. Cirebon. Dari hasil penelitian yang dilakukan maka didapatkan data mengenai respon siswa terhadap Penggunaan Software Cabri 3D, minat siswa dan nilai hasil tes matematika siswa. 
Berdasarkan hasil analisis data respon 29 siswa terhadap penggunaan Software Cabri $3 D$ pada mata pelajaran matematika diperoleh rata-rata sebesar 91,72 dengan skor maksimum adalah 99. Hal ini menunjukan bahwa kebanyakan siswa memberikan respon yang baik dan positif terhadap penggunaan Software Cabri $3 D$. Hal ini selaras dengan hasil perolehan skor respon minimum siswa terhadap penggunaan Software Cabri $3 D$ sebesar 82. Sedangkan nilai standar deviasi sebesar 4.992 yang menunjukan arti bahwa penyimpangan skor dari keseluruhan siswa dari skor rata-rata respon terhadap penggunaan Software Cabri $3 D$ tidaklah jauh dari skor rata-rata respon keseluruhan siswa yaitu 91,72. Disamping itu, diperoleh nilai varians respon siswa terhadap penggunaan Software Cabri $3 D$ sebesar 24,921 yang menunjukan arti bahwa terdapat banyak ragam respon siswa terhadap penggunaan Software Cabri $3 D$ yang memberikan respon baik. Dan hasil persentase hasil respon siswa terhadap penggunaan Software Cabri 3D maka diperoleh persentase rata-rata dari seluruh indikator respon siswa terhadap penggunaan Software Cabri $3 D$ adalah $67 \%$ dengan kriteria baik.

Hal yang terutama harus dimiliki oleh siswa dalam pembelajaran matematika di sekolah adalah minat terhadap belajar matematika. Siswa yang memiliki minat yang tinggi biasanya akan memberikan hasil belajar matematika yang baik. Salah satu cara untuk menimbulkan minat belajar siswa dalam belajar matematika adalah penggunaan Software Cabri 3D. Hal ini di buktikan dengan hasil angket minat belajar siswa yang disebar kepada 29 siswa sebelum menggunakan Software Cabri $3 D$ dan setelah menggunakan Software Cabri 3D. Data hasil angket minat sebelum menggunakan Software Cabri $3 D$ diperoleh rata-rata 77,38 dan setelah menggunakan Software Cabri $3 D$ diperoleh rata-rata 82,86 . Nilai maksimum siswa sebelum menggunakan Software Cabri $3 D$ adalah 84 dan nilai maksimum setelah menggunakan Software Cabri $3 D$ adalah 94. Sedangkan nilai minimum sebelum menggunakan Software Cabri $3 D$ adalah 70 dan nilai minimum setelah menggunakan Software Cabri $3 D$ adalah 77. Untuk standar deviasi sebelum menggunakan Software Cabri 3D diperoleh 3,064 dan setelah menggunakan Software Cabri $3 D$ diperoleh 3,824. Sedangkan variansi sebelum menggunakan Software Cabri $3 D$ diperoleh
9,387 dan variansi setelah menggunakan Software Cabri $3 D$ diperoleh 14,623. Selain itu, persentase data hasil angket minat siswa sebelum menggunakan Software Cabri 3D diperoleh 59\% dan persentase setelah menggunakan Software Cabri $3 D$ sebesar $63 \%$. Dari data tersebut, maka terdapat peningkatan minat belajar sebelum dan setelah menggunakan Software Cabri $3 D$.

Setelah penggunaan Software Cabri $3 D$ dilakukan pada kelas penelitian. Kemudian peneliti melakukan tes hasil belajar matematika siswa setelah menggunakan Software Cabri 3D. Hasil yang diperoleh dari tes matematika siswa dengan rata-rata sebesar 72,93. Hal ini menunjukan bawa rata-rata siswa telah mencapai hasil tes matematika yang sangat baik setelah menggunakan Software Cabri 3D. Hal ini selaras dengan dengan hasil perolehan skor minimal sebesar 40 dan skor maksimal sebesar 90. Sedangkan nilai standar deviasi sebesar 14,911 yang menunjukan arti bahwa penyimpangan skor keseluruhan siswa tidaklah jauh dari skor rata-ratanya yaitu 72,93. Disamping itu, diketahui nilai variansi sebesar 222,352 yang menunjukan arti bahwa jawaban siswa memiliki keberagaman yang tinggi dan tidak ada kesamaan jawaban secara signifikan. Hasil tes matematika diperoleh range sebesar 50 yang menunjukan bahwa terdapat perbedaan yang cukup jauh antara jawaban siswa terhadap soal matematika yang diberikan. Hal ini dapat dilihat dari skor minimum sebesar 40 dan maksimum sebesar 90.

Dari perolehan data respon siswa terhadap penggunaan Software Cabri $3 D$, minat dan hasil belajar matematika siswa. Selanjutnya peneliti melakukan tes normalitas data untuk mengtahui apakah data memiliki distribusi normal untuk melanjutkan tahap analisis selanjutnya.

Hasil pengujian normalitas data menggunakan Software SPSS 20, diperoleh signifikansi pada tabel 4.15 kolmogorov smirnov sebesar 0,136 dengan taraf a sebesar 0,05. Dikarenakan hasil tes signifkansi lebih dari a atau 0,136 > 0,05 maka dapat disimpulkan bahwa data penelitian yang diperoleh dari penyebaran angket dan tes matematika pada sampel penelitian adalah berdistribusi normal.

Selanjutnya dilakukan tes homogenitas untuk mengetahui apakah data memiliki distribusi yang homogen dengan menguji varians dari data penelitian yang diperoleh. 
Berdarkan hasil uji homogenitas diketahui signifikansi 0,102 untuk hasil belajar siswa dan diketahui signifikansi 0,108 untuk minat belajar dengan taraf a sbeesar 0,05. Dikarenakan signifikansi lebih besar dari a atau $0,102>0,05$ dan $0,108>0,05$ maka disimpulkan data berdisribusi homogen. Dengan kata lain, keadaan siswa dalam sampel penelitian memiliki varians yang baik ditinjau dari data perolehan angket respon terhadap penggunaan Software Cabri $3 D$ dan tes matematika siswa pada pokok bahasan bangun ruang sisi lengkung.

Dari hasil pengujian normalitas dan homogenitas selanjutnya penelitian melakukan analisis data lebih lanjut untuk mengetahui apakah terdapat pengaruh antara penggunaan Software Cabri $3 D$ terhadap hasil belajar matematika siswa.

Dari hasil analisis data diperoleh korelasi antara penggunaan Software Cabri $3 D$ terhadap hasil belajar matematika sebesar 0,342. Nilai korelasi menunjukan hasil yang positif maka menunjukan pengaruh yang positif pula. Nilai koefisien determinasi pada tabel 4.18 diperoleh $\mathrm{R}$ Square sebesar 0,351. Hal ini menunjuan bahwa terdapat $21,7 \%$ sumbangsih tehadap hasil belajar matematika siswa dan sisanya dipengaruhi oleh variabel lain yang tidak digunakan dalam penelitian ini.

Ditinjau dari linieritas regresi diperoleh hasil signifiansi linerity sebesar 0,012. Dikarenakan 0,012 lebih kecil dari 0,05 artinya terhadap hubungan yang linier antara penggunaan Software Cabri 3D terhadap hasil belajar matematika pada pokok bahasan bangn tuang sisi lengkung. Sedangkan kebaikan model regresi dikeatahui $\hat{Y}=58,821+0,262 X$ menunjukan bahwa jika penggunaan Software Cabri 3 Dnya 0 maka hasil belajar siswa nilainya sebesar 0.262 .

Koefisien regresi variabel penggunaan Software Cabri $3 D$ sebesar 0,262 menunjukan jika penggunaan Software Cabri 3D mengalami kenaikan satu satuan, maka hasil belajar siswa akan mengalami peningkatan sebesar 0,262 satuan. Koefisien regersi yang bernilai positif, ini menunjukkan bahwa hubungan antara penggunaan Software Cabri $3 D$ dengan hasil belajar siswa adalah positif. Artinya semakin tinggi penggunaan Software Cabri $3 D$ maka semakin meningkatkan hasil belajar siswa.

Uji hipotesis diperoleh bahwa signifikansi sebesar 0,000 dan thitung dari minat belajar sebesar 10,600 sedangkan thitung dari hasil belajar sebesar 10,461. Berdasarkan uji hipotesis statistik pada bab III, maka dapat disimpulkan bahwa Ho ditolak. Hal ini ditunjukan karena signifikansi lebih kecil dari a atau $0,000<$ 0,05 dan thitung $>t_{\text {tabel }}$ atau 10,600 $>2,048$ dan $10,461>2,048$. Sehingga diketahui terdapat pengaruh yang signifikan dari penggunaan Software Cabri $3 D$ terhadap hasil belajar siswa.

Berdasarkan hasil pembahasan di atas dapat diketahui terdapat pengaruh yang positif terhadap minat dan hasil belajar matematika siswa kelas IX A SMP AsySyahida Dukupuntang Cirebon setelah penggunaan Software Cabri 3D.

\section{PENUTUP}

\section{Kesimpulan}

Berdasarkan hasil penelitian dan pengembangan yang telah dilakukan oleh peneliti di SMP Asy-Syahida Dukupuntang, maka peneliti dapat menarik kesimpulan sebagai berikut: 1) Respon Penggunaan Software Cabri $3 D$ pada kelas IX A SMP AsySyahida Dukupuntang memiliki rata-rata sebesar $67 \%$ dengan katagori baik. 2) Hasil belajar siswa dengan menggunakan Software Cabri $3 D$ melalui tes tentang materi bangun ruang sisi lengkung dengan rata-rata sebesar 72, 93 termasuk dalam kategori baik. Nilai rata-rata tersebiut lebih besar dari nilai KKM = 68 yang berarti efektif. 3) Lewat analisis statistik, dihasilkan nilai R-Square 0,217 atau $21,7 \%$. Artinya terdapat pengaruh positif sebesar $21,7 \%$ ketika menggunakan Software Cabri $3 D$ terhadap minat dan hasil belajar siswa. Terdapat pengaruh yang signifikan dari penggunaan Software Cabri $3 D$ terhadap minat dan hasil belajar siswa melalui hasil tes dengan nilai uji hipotesis diperoleh thitung $>$ tabel $(10,146>2,048)$ dengan demikian $\mathrm{H}_{0}$ ditolak dan $\mathrm{H}_{\mathrm{a}}$ diterima. Dan terjadi hubungan yang positif antara penggunaan Software Cabri $3 D$ dengan minat dan hasil belajar siswa jika dilihat dari nilai koefisien regresi dengan persamaan regresiyaitu $\hat{Y}=58,821+0,262 X$. Hasil dari persamaan tersebut dengan koefisien regresi bernilai positif yaitu sebesar 0,262. Ditinjau dari uji sampel paired $t$ test terjadi peningkatan rata-rata sebesar 32,241 dengan alfa $5 \%$. Berdasarkan hal tersebut, dapat peneliti katakan bahwa penggunaan Software Cabri $3 D$ pada pokok bahasan bangun ruang sisi lengkung dinyatakan 
layak dan efektif untuk digunakan dalam ruang lingkup yang lebih luas.

\section{Saran}

Berdasarkan kesimpulan di atas, dikemukakan beberapa saran diantaranya : (1) Dalam kegiatan belajar mengajar hendaknya guru menggunakan media pembelajaran guna meningkatkan minat dan hasil belajar siswa. (2) Berdasarkan hasil penelitian ini diharapkan kepada guru matematika SMP Asy-Syahida Dukupuntang agar menjadikan media pembelajaran sebagai salah satu alat bantu pembelajaran bagi siswa. (3) Melalui penggunaan media pembelajaran dapat menjadi alternatif pembelajaran guru untuk meningkatkan motivasi dan hasil belajar yang lebih baik. (4) Selain penggunaan media pembelajaran Software Cabri $3 D$ ternyata masih banyak faktor lain yang mempengaruhi hasil belajar siswa. Oleh kaerena itu, perlu dikembangkan penelitipeneliti berikutnya untuk menemukan faktor -faktor lain yang mempengaruhi hasil belajar siswa, guna meningkatkan kualitas belajar siswa.

\section{DAFTAR PUSTAKA}

Abduh, M.Faisal dan Aditya Nursasongko. "Pengembangan Pembelajaran Matematika Berbasis ICT : Penerapan Cabri." t.thn.

Anton, M, Mulyono. Aktivitas Belajar. Bandung: Yrama, 2001.

Arsyad, Azhar. Media Pembelajaran. Jakarta: PT RajaGrafindo Persada, 2011.

Cabrilog. http://www.cabri.com/downloadcabri-3d.html. t.thn. (diakses 03 03, 2016).

http://www.cabri.com/v2/pages/fr /products_cabri3d_tutorials.php. t.thn. (diakses 03 03, 2016).

Darmawan, Deni. Pendidikan Teknologi Informasi Dan Komunikasi. Bandung: PT Remaja Rosdakarya, 2012.

Daryanto. 2010. Media Pembelajaran. Yogyakarta: Gava Media.

Fauzi, Ahmad. Manajemen Pembelajaran. Yogyakarta: CV BUDI UTAMA, 2014.
Manfaat, Budi \& Toto Syatori. 2015. Dasardasar Metodologi Penelitian Cetakan Pertama. Cirebon: Eduvision.

Nasution, S. 2011. Teknologi Pendidikan.

Jakarta: PT Bumi Aksara.

Sudjana, Nana. Dasar-Dasar Proses Belajar Mengajar. Bandung: Sinar Baru Algensindo, 2002.

Sugiono. Metode Penelitian Kuantitatif dan Kualitatif dan R\&D. Bandung: Alfabeta, 2011.

Warsita, Bambang. Teknologi Pembelajaran landasan \& Aplikasinya. Jakarta: Rineka Cipta, 2008. 